\title{
Effect of Certain Dinacharya Measures and Dietary Practices on Quality of Life of Elderly: A Cross Sectional Survey Study
}

\author{
Research Article
}

\section{Prajna Paramita Panda1, Shiva Kumar Harti², Mangalagowri V Rao ${ }^{\text {* }}$}

\author{
1. Ayurvedic Medical Officer, Govt. Ayurvedic Dispensary, Andola, Jajpur, Odisha. \\ 2. Associate Professor, Department of Swasthavritta, \\ All India Institute of Ayurveda, Gautam Puri, Sarita Vihar, New Delhi. \\ 3. Associate Professor, Department of Swasthavritta and Yoga, Faculty of Ayurveda, \\ Institute of Medical Sciences, Banaras Hindu University, Varanasi.
}

\begin{abstract}
Old age is sensitive period of life that needs extra care, so as to manage many of age related disorders that affect the quality of life of an elderly. As per Ayurveda, Ageing is a natural phenomenon. To achieve the goal of maintaining the health, Dinacharya (daily regimen), which includes certain measures like body massage, head and feet massage, incorporation of milk and ghee in diet due to their rejuvenating effect and many more simple and effective modes. Aims: To assess the effect of certain Dinacharya (daily regimen) and dietary practices on quality of life of elderly Methodology: Cross sectional survey of 100 elderly in age group 60-90yrs residing in and around Delhi NCR was conducted. The data was collected with the help of specially designed questionnaire about practices of daily regimens and EQ-5D-5L questionnaire to assess quality of life. Observations and Results: The study shows that $72 \%$ subjects had poor to average score with respect to EQ 5D scale. Regular adoption of daily regimen in the form of exercise (36\% subjects), intake of milk (46\% subjects) Intake of ghee (13\% subjects), proper sleep ( $85 \%$ subjects) and body massage with oil (39\% subjects) and head massage with oil (39\% subjects) is moderate. Conclusion: Old age being a vulnerable period of life, healthy regimen should be adopted as early as possible to experience less morbidity during old age. Extensive adaptation of daily regimen as mentioned in Ayurveda is needed to reduce the health care burden causes due to geriatric dependency.
\end{abstract}

Key Words: Daily regimen, Padabhyanga, Shirobhyanga, Milk, Ghee.

\section{Introduction}

Old age covers $30-40 \%$ of life of an individual on considering life expectancy to be $80-100$ years. It enhances financial burden due to increasing incidence of illness during old age. As per Ayurveda, Aging is a natural phenomenon. As the age advances occurrence of chronic diseases like diabetes, hypertension, cardiac ailments, nutritional deficiencies, osteoporosis, psychological ailments like depression and other associated conditions increases. Ayurveda has a major role in increasing the quality of life as age progresses.

Ayurveda advocates, simple and efficient modality Dinacharya (daily regimen) for health promotion, longevity and disease prevention. Dinacharya (daily regimen) in Ayurveda includes early waking up, timely sleep, exercise various procedures like Nasya (nasal instillation of oil), Abhyanga (body

* Corresponding Author:

Mangalagowri V Rao

Associate Professor, Department of Swasthavritta and

Yoga, Faculty of Ayurveda,

Institute of Medical Sciences,

Banaras Hindu University, Varanasi, India - 221005

Email Id: mangowri@gmail.com massage with oil), Shirobhyanga (head massage with oil), Padabhyanga (foot massage with oil) etc.

Milk and Ghee are best rejuvenating (1) food items for daily intake (2). Hence, the present study was carried out to know the effect of certain Dinacharya (daily regimen) measures and use of milk and ghee in geriatric population.

\section{Objective}

To assess the effect of certain Dinacharya (daily regimen) and dietary practices on quality of life of elderly.

\section{Materials and Methods}

The persons residing in and around the Delhi NCR were interviewed after taking their consent. One hundred subjects belonging to 60-90 years of age group were randomly selected and surveyed about their health conditions along with their daily regimen history as per designed short format.

\section{Types of study design \\ Cross-sectional Study \\ Setting}

Subjects attending OPDs of All India Institute of Ayuveda, New Delhi and Delhi NCR. 
Mangalagowri V Rao et.al., Effect of certain Dinacharya measures and dietary practices on Quality of Life of Elderly

Inclusion

1. Age -60 year to 90 year.

2. Both the gender.

\section{Exclusion}

1. People unwilling to participate in the study.

2. Individuals below 60 years above 90 years.

\section{Sample size calculation}

The sample size for the cross sectional studies are calculated as following formula (3)

$$
\mathrm{N}=\mathrm{Z}^{2} \times \mathrm{P}(1-\mathrm{P}) / \mathrm{d}^{2}
$$

Where $\mathrm{Z}=$ level of confidence; $\mathrm{P}=$ expected prevalence; $\mathrm{d}=$ precision

For this study we assumed $\mathrm{P}=0.6$ and $\mathrm{d}=0.1$ at $95 \%$ level of confidence
Then

$$
\begin{gathered}
\mathrm{N}=(1.96)^{2} \times 0.6 \times 0.4 /(0.1)^{2} \\
=0.921984 / 0.01 \\
=92.1984
\end{gathered}
$$

Again minimum sample size for conducting survey study is 100 . (4)

\section{Survey Tool}

I. EQ-5D-5L - The 5-level EQ-5D version (EQ-5D-5L) was introduced by the Euro Qol Group in 2009 to improve the instrument's sensitivity and to reduce ceiling effects, as compared to the EQ-5D-3L. The EQ-5D-5L essentially consists of 2 pages: the EQ-5D descriptive system and the EQ visual analogue scale (EQ VAS) (5)

II. A specially designed questionnaire to know the Dinacharya (daily regimen) practices in elderly people.

\section{Observations and Results}

The data collected were systematically entered in the Microsoft excel sheets. The analysis of data was also done by using Microsoft excel. The subjects of the study were categorized in to three age groups as shown in the Table-1.

Table 1: Distribution of Subjects according to age group ( $N=100)$.

\begin{tabular}{|l|c|}
\hline Age group & No of participants \\
$60-70$ years & 83 \\
$70-80$ years & 12 \\
$80-90$ years & 5 \\
\hline
\end{tabular}

Table 2: Distribution of Subjects according to gender $(\mathrm{N}=100)$.

\begin{tabular}{|c|c|}
\hline Gender & No. of Participants \\
Male & 53 \\
\hline Female & 47 \\
\hline
\end{tabular}

Table 3: Distribution of subjects according to their health complaints $(\mathbf{N}=100)$.

\begin{tabular}{|l|c|c|c|c|c|}
\multicolumn{1}{|c|}{ Dimensions } & No complaint & Mild & Moderate & Severe & $\begin{array}{c}\text { Unable to perform/ } \\
\text { extreme }\end{array}$ \\
\hline Mobility & 26 & 34 & 25 & 14 & 1 \\
\hline Self-care & 32 & 52 & 13 & 3 & 0 \\
\hline Usual activity & 30 & 36 & 26 & 3 & 5 \\
\hline Pain and Discomfort & 19 & 47 & 15 & 12 & 7 \\
\hline Anxiety and Depression & 13 & 52 & 32 & 3 & 0 \\
\hline
\end{tabular}

Table 4: Distribution of subjects according to their general wellbeing $(\mathrm{N}=100)$.

\begin{tabular}{|c|c|c|c|c|}
\hline SI. No & Score & Interpretation & Number & Percentage \\
\hline 1 & $40-55$ & Poor & 13 & 13 \\
\hline 2 & $55-70$ & Average & 59 & 59 \\
\hline 3 & $70-85$ & Good & 25 & 25 \\
\hline 4 & $85-100$ & Very good & 3 & 3 \\
\hline
\end{tabular}

Table 5: Distribution of subjects according to their Dinacharya practices $(\mathrm{N}=100)$.

\begin{tabular}{|l|c|c|c|c|c|}
\hline \multicolumn{1}{|c|}{ Regimens } & Daily & Twice in a week & Once in a week & Occasionally & Never \\
\hline Exercise & 36 & 1 & 3 & 13 & 47 \\
\hline Milk intake & 46 & 0 & 4 & 28 & 22 \\
\hline Ghee intake & 13 & 3 & 2 & 36 & 46 \\
\hline Day sleep & 48 & 4 & 0 & 30 & 18 \\
\hline Awakening at night & 15 & 0 & 0 & 43 & 42 \\
\hline Oil massage on body & 39 & 10 & 2 & 21 & 28 \\
\hline Head Massage & 39 & 26 & 8 & 19 & 8
\end{tabular}




\section{Discussion}

\section{Exercise}

About $47 \%$ among elderly never exercised and $16 \%$ rarely exercised (Ref. Table 5 ). That may be the reason for poor to average scores among $59 \%$ and $13 \%$ respectively among elderly in the study (Ref. Table 4). It may also contribute to the high proportion $(19 \%$ severe and $15 \%$ moderate) of pain and discomfort and anxiety and depression (32\% moderate and $3 \%$ severe) in the study group (Ref Table No. 3). Exercise gives stability (6). Exercise is a solution for various noncommunicable diseases like diabetes, obesity, hypertension etc. Research in India, show a prevalence from $13 \%$ to $25 \%$, which is similar to observations in present study (7). Corticosterone secretions are enhanced in psychological disorders (8). The hypothalamus releases corticotrophin-releasing factor (CRF) and anterior pituitary releases ACTH after Voluntary exercise. (9) (10) Hence, physical, psychosomatic and psychological aliments can be prevented as well as managed by regular exercise in geriatric population.

\section{Milk and ghee intake}

The study shows that $46 \%$ of subjects were taking milk daily (Ref. Table 5) which may be the cause that only $15 \%$ of people had severe mobility disorder (Ref. Table 3). Because as per Ayurveda Cow's milk and ghee are best among Rasayana Dravyas. Depletion of tissues (Dhatu Kshaya) occurs in old age due to aggravation of Vata and milk and ghee pacify Vata and promote formation of tissue (Dhatu) (11) (12). Milk is considered as complete food and a rich source of calcium (13). Milk also contains micronutrients like phosphorous, Retinol, Riboflavin, Niacin and folic acid which are helpful for preventing early aging (14).

\section{Day sleep}

Forty-eight subjects were sleeping at day time (Ref. Table 5) which may be the cause for high prevalence $(19 \%)$ of pain and discomfort (Ref. Table 3). Day sleep aggravates Kapha which may obstruct the channels (15). The channel obstruction may further reduce Dhatu Poshana. Reduced Dhatu Poshan can again cause early aging.

\section{Awakening at night}

Only $15 \%$ of subjects were awakening at night which shows that rest of subjects had good sleep (Ref. Table 5). Old age is a stage of Vata predominance (16). Awakening at night further increases Vata (17). The increased Vata reduces Bala (Strength/vitality) of the body.

\section{Body and head massage with oil}

About $39 \%$ of subjects practiced Massage daily

(Ref. Table 4). Massage is indicated daily and will be very much helpful in geriatric population as it pacifies Vata and nourishes Dhatus (18). This may be the reason for good sleep at night among 85\% (Ref. Table 5). Further, this may be the reason for majority $(66 \%)$ of subjects experiencing no or mild pain despite of their old age (Ref. Table 3). The score in self-care and usual activity (68\% and $70 \%$ respectively Ref. Table 3 ) was not much satisfactory which may be the cause of 59\% (Ref. Table 4) of subjects were having average general wellbeing score.

\section{Limitation of the study}

This is a pilot study comprising only 100 subjects and only in Delhi NCR. Large sample study is needed for the complete evaluation.

\section{External Validity of study}

Over all it has been observed that the quality of life was better in subjects following practices in daily regimen like exercise, body and head massage with oil and healthy sleeping habits. These are very simple costeffective measures that can be implemented in one's life for health promotion and better quality of life especially in country like India.

\section{Conclusion}

The study shows that $72 \%$ subjects had poor to average score with respect to EQ 5D. Regular adoption of daily regimen in the form of exercise (36\% subjects), intake of milk (46\% subjects) Intake of ghee (13\% subjects), proper sleep (85\% subjects) and body massage with oil (39\% subjects) and head massage with oil (39\% subjects) is moderate. Old age being a vulnerable period of life, healthy regimen should be adopted as early as possible to experience less morbidity during old age. Extensive adaptation of daily regimen as mentioned in Ayurveda is needed to reduce the health care burden causes due to geriatric dependency.

\section{Reference}

1. Acharya YT, editor. Charaka Samhita of Agnivesha, Reprint edition. Varanasi; Chaukhamba Orientalia; 2011, Page 132.

2. Acharya YT, editor. Charaka Samhita of Agnivesha, Reprint edition. Varanasi; Chaukhamba Orientalia; 2011, Page 38.

3. Mohamad Amin Pourhoseingholi,Mohsen Vahedi and Mitra Rahimzadeh, Sample size calculation in medical studies, Gastroenterol Hepatol Bed Bench. 2013 Winter; 6(1): 14-17.

4. www.tools4dev.org > resources > how-to-choose-asample size. Dated 25.10.2020 time 00.11 IST.

5. Devlin NJ, Brooks R, EQ-5D and the Euro Qol Group: Past, Present and Future, Appl Health Econ Health Policy. 2017 Apr;15(2):127-137.

6. Acharya YT, editor. Charaka Samhita of Agnivesha, Reprint edition. Varanasi; Chaukhamba Orientalia; 2011, Page No. 131.

7. Dimple Madhukar Jamkhandi, Sara Bhattacharji, Profile of elderly attending a general practice clinic in a poor urban area: A cross-sectional study from South India, J Family Med Prim Care. 2016 OctDec; 5(4): 792-797. 
8. Irwin J, Ahluwalia P, Zacharko RM, Anisman H, Central norepinephrine and plasma corticosterone following acute and chronic stressors: influence of social isolation and handling., Pharmacol Biochem Behav. 1986 Apr; 24(4):1151-4.

9. Salmon $P$, Effects of physical exercise on anxiety, depression, and sensitivity to stress: a unifying theory.Clin Psychol Rev. 2001 Feb; 21(1):33-61.

10. Droste SK, Gesing A, Ulbricht $S$, Müller $M B$, Linthorst $A C$, Reul JM, Effects of long-term voluntary exercise on the mouse hypothalamicpituitary-adrenocortical axis.,Endocrinology. 2003 Jul; 144(7):3012-23.

11. Hari Sadasiva Shastri Paradakar, editor. Astanga Hridaya of Vagbhatta, Reprint Edition. Varanasi: Chaukhamba surbharati prakashan; 2009.

12. Acharya Priya Vrit Sharma, editor. Sushruta Samhita of Dhanvantari, Reprint edition. Varanasi; Chaukhamba Orientalia; 2007, Page 204.
13. Nutritive values of Indian Foods by C Gopalan, B V Shastri, S C Bala Subranian revised and updated by B S Narasinga Rao, Y G Deosthale and K C Pant, National Institution of Nutrition 1989, Page 57.

14. Mangalagowri V Rao, A Textbook of Swasthavritta, Chaukhambha Orinetalia, Varanasi, 2017, Page 149

15. Acharya YT, editor. Charaka Samhita of Agnivesha, Reprint edition. Varanasi: Chaukhamba Orientalia; 2011, Page No. 118.

16. Hari Sadasiva Shastri Paradakar, editor. Astanga Hridaya of Vagbhatta, Reprint Edition. Varanasi: Chaukhamba surbharati prakashan; 2009.

17. Acharya Priya Vrit Sharma, editor. Sushruta Samhita of Dhanvantari, Reprint edition. Varanasi: Chaukhamba Orientalia; 2007, Page No.359.

18. Hari Sadasiva Shastri Paradakar, editor. Astanga Hridaya of Vagbhatta, Reprint Edition. Varanasi: Chaukhamba surbharati prakashan; 2009. 